\title{
Wymiary postawy posłuszeństwa w wybranych kazaniach Fabiana Birkowskiego OP (1566-1636)
}

Postawa posłuszeństwa człowieka wobec Boga jest jednym z najważniejszych profilów jego duchowego życia, które rozciąga się pomiędzy nawróceniem z grzechów a mistyczną unią wiodącą do widzenia uszczęśliwiającego. W tym procesie posłuszeństwo jawi się jako warunek konieczny, ponieważ poprzez podporządkowanie człowieka woli Bożej pozwala mu wejść w świat wartości nadprzyrodzonych i osiągnąć przewidziane dla niego dobra. Także na gruncie wczesnonowożytnej duchowości katolickiej, ukształtowanej zwłaszcza przez sobór trydencki zagadnienie to posiada szczególne znaczenie, gdyż tworzy zasadniczą regułę postępowania i współpracy $\mathrm{z}$ łaską. $\mathrm{W}$ przeciwieństwie do reformatorów katolicy podkreślają, że pokora jest wyrazem autentycznej ludzkiej współpracy z Bogiem, związanej z takimi wartościami, jak zasługa, zapłata czy realny wpływ człowieka na własne zbawienie.

Pośród wielu autorów również Fabian Birkowski (1566-1636), polski dominikanin i szeroko znany kaznodzieja, który w pewnym sensie przejął po śmierci Piotra Skargi zadanie ideowego przewodzenia Kościołowi w Polsce ${ }^{1}$, podejmuje problematykę posłuszeństwa, aby ukazać jego istotę oraz ważne wymiary, takie jak pokora, życie ukryte, naśladowanie Chrystusa, służba, ofiarowanie siebie, a nawet mistyczna unia. W tej gamie form człowiek wyraża podporządkowanie siebie łasce Bożej. Jedynie w powierzchownej obserwacji sens posłuszeństwa może być uznany za stratę, w rzeczywistości bowiem wprowadza ono w głąb radykalnego doświadczenia prawdziwego szczęścia i radości. W tej perspektywie samoograniczenie podmiotu, nazywane w dzisiejszej terminologii przejściem od fałszywego do prawdziwego ,ja" $(\text { false self-true self })^{2}$, zyskuje swój właściwy, pozytywny sens jako środek do celu.

\footnotetext{
${ }^{1}$ Por. C. Hernas, Barok, Warszawa 2002, s. 384.

${ }^{2}$ Ta idea została szeroko rozwinięta w teologii duchowości XX i XXI wieku. Por. J. Main, Chrześcijańska medytacja, tłum. Benedyktyni tynieccy, Kraków 1992, s. 43-47; T. Keating, Zaproszenie do miłości, tłum. K. Pachocki, Poznań 2005, s. 15-26; L. Freeman, Światło wewnętrzne. Droga medytacji chrześcijańskiej, tłum. A. Wojtasik, Kraków 2006, s. 36-60.
} 
Punktem wyjścia poniższej analizy jest biblijna scena znalezienia Jezusa w Świątyni oraz Jego późniejsze poddanie Maryi i Józefowi w Nazarecie (por. Łk 2, 41-52) . $^{3}$ $Z$ tego miejsca wyprowadzone zostają różne wymiary posłuszeństwa. Rezultaty analizy dwóch kazań Birkowskiego, zaczerpniętych z jego ważnego zbioru ${ }^{4}$, zostaną tu ujęte w cztery punkty. Na tle egzystencjalnej sytuacji człowieka wezwanego do okazania posłuszeństwa Bogu (1) będzie zarysowana sylwetka Chrystusa, najważniejszego przykładu dla człowieka (2), a następnie ukazana zostanie wizja całościowego zaangażowania życia duchowego w proces posłuszeństwa (3), co w sposób szczególny wyraża się także w rzeczywistości mistycznej (4).

\section{Sytuacja egzystencjalna człowieka i jego wolny wybór}

Nauczanie Birkowskiego na temat sytuacji egzystencjalnej rodzaju ludzkiego skupia się na jego pochodzeniu oraz na stanie grzechu. Jako byt stworzony człowiek jest w całości określany przez Boga, a tę jego kondycję oddają słowa: „,niepożyteczni słudzy"5 czy motyw gliny, z której został on uformowany (por. Rdz 2, 7). W ten metaforyczny sposób przypisano mu cechę pasywności, która ma znaczenie metafizyczne: ,[jesteśmy] glina prosta w rękach jego, z której on może ulepić, co chce”. Człowiek nie posiada w sobie żadnego powodu do dumy, lecz to łaska Boża panuje nad nim tak, że niczego nie może bez niej uczynić. Motyw gliny wyraża totalną zależność od Boga zarówno w sensie istnienia, jak i istoty.

Jednak bierność nie wyklucza ludzkiego czynu, każdy bowiem może dokonać wyboru i kształtować jego konsekwencje ${ }^{7}$. Człowiek jest ciągle wzywany do wyboru Boga i Jego drogi życia, która wyraża się między innymi w posłuszeństwie, pokorze i życiu ukrytym ${ }^{8}$. Można to odczytać w koncepcji stworzenia, w której posłuszeństwo odgrywa rolę zasadniczą:

Wyciąga to na tobie natura twoja stworzona na poddaństwo, boś na to stworzony, abyś Bogu był posłuszny, na tym poddaństwie stanęło szczęście ostateczne twoje?

${ }^{3}$ Oznaczenia biblijne ujednolicone według: Pismo Święte Starego i Nowego Testamentu w przekładzie z języków oryginalnych, oprac. zespół biblistów polskich z inicjatywy Benedyktynów tynieckich, Poznań 1996 (Biblia Tysiaclecia, wyd. IV).

${ }^{4}$ Kazania na Niedziele i Święta Doroczne przez X.D. Fabiana Birkowskiego Zakonu św. Dominika Kaznodziejskiego napisane i wydane. Na każda Niedzielę po dwojgu kazań i na Święta przedniejsze $z$ dozwoleniem starszych cum gratia \& privilegio S.R. M., Kraków 1620, s. 74-87. Cytaty z zastosowaniem transkrypcji i uzupełnień interpunkcyjnych.

${ }^{5}$ F. Birkowski, Kazania..., s. 74.

${ }^{6}$ Tamże.

${ }^{7}$ Koncepcja Birkowskiego wyrażająca nauczanie Kościoła rzymskiego różni się szczególnie w tym punkcie zarówno od kwietyzmu, jak i od antropologicznej wizji charakterystycznej dla Reformacji.

${ }^{8}$ Św. Franciszek Salezy zwraca uwagę, że pokora oznacza przyjęcie Bożego wezwania, podczas gdy uchylanie się od niego, maskowane pozorną małością człowieka, jest właściwe pysze. Por. F. Salezy, Filotea, czyli droga do życia pobożnego, tłum. H. Libiński, Olsztyn 1985, s. 138.

${ }^{9}$ F. Birkowski, Kazania..., s. 76. 
Posłuszeństwo jest ludzką odpowiedzią na Boży plan i sposobem uczestnictwa w nim dla osiągnięcia dóbr przygotowanych przez Boga. Tylko ten, kto słucha głosu Stworzyciela, może być obdarzony bogactwem i nasycony w pełni. Biblijne ujęcie tego stanu zawiera kluczowy werset: „Ut sit Deus omnia in omnibus” (por. 1 Kor $15,28)^{10}$ pojmowany przez polskiego autora jako wypełnienie ludzkiego serca. Tego dokonać może jedynie Bóg, który „,[ma być] kresem wszytkich chuci naszych, oprócz którego nie masz nic, co by nas słusznie ucieszyć miało"11. Człowiek jest istotą wezwaną do udzielania ciągłej pozytywnej odpowiedzi kochającemu Bogu aż po wiekuiste szczęście. Chociaż sam w sobie jest on kimś nagim, bierną gliną, to wtedy gdy zaczyna współpracować z Bogiem, staje się bogaty i szczęśliwy ${ }^{12}$. Bytowa struktura człowieka jest dialogiczna i wyraża się w posłuszeństwie.

Kto wyłącza siebie z relacji podporządkowania, ten pozostaje samotny w obliczu rozmaitych zdarzeń i nawet niepozorny aspekt przyszłości (,lada nędza”) może stać się źródłem jego lęku ${ }^{13}$. W tym kontekście pojawia się problem grzechu, który pogłębia ten stan. Na przykład „duma” jest „wrogiem” Boga i nosi miano „hardości przeklętej"14. Rezultat grzechu śmiertelnego został przedstawiony w porównaniu do zagubienia Jezusa w Świątyni:

Trzecia zguba jest Pana Zbawiciela naszego, gdy go grzeszni przez grzech śmiertelny tracą. Zguba nad inne najżałośniejsza, która się inaczej nie nagradza, jedno gdy prawdziwie pokutować będą przez trzy dni z boleścią szukając Pana, to jest przez skruchę, spowiedź i zadosyćuczynienie ${ }^{15}$.

Grzech śmiertelny jest aktem całkowitego odrzucenia Boga, Jego planu i związanych z nim dóbr, co pociąga za sobą wieczne potępienie. Odwrócenie tego stanu dokonuje się poprzez głębokie posłuszeństwo wyrażone w formule sakramentalnego pojednania. Poddanie siebie Bogu u swych korzeni ma zatem także wymiar sakramentalny.

W przeciwieństwie do tego każdy, kto wypełnia wolę Stwórcy, cieszy się bezpieczeństwem w ciągu swego życia. Na skutek działania Opatrzności nie obawia się on ziemskich lęków ani też nie żywi próżnych nadziei, a z drugiej strony chętnie przyjmuje wszystko jako dopuszczone za zgodą Boga ${ }^{16}$. Jeżeli nawet religijna zależność nie chroni go od pewnych trudnych przeżyć, to dostarcza mu mocy potrzebnej do wyciągnięcia z nich korzyści. Ponadto zapewnia mu ochronę przed złem: ,czart do nas nie przystąpi, bo ten nikogo nie zepchnie, aż pierwej namówi na wypowiedzenie posłuszeństwa" ${ }^{17}$. Postawa posłuszeństwa tworzy rodzaj matrycy

\footnotetext{
${ }^{10}$ Por. tamże, s. 74, 76.

${ }^{11}$ Tamże, s. 74.

${ }^{12}$ Por. A. Louf, Pokora i postuszeństwo, tłum. Benedyktyni tynieccy, Kraków 2004, s. 54-64.

${ }^{13}$ Por. F. Birkowski, Kazania..., s. 76.

${ }^{14}$ Tamże, s. 78.

${ }^{15}$ Tamże, s. 87.

${ }^{16}$ Por. tamże, s. 76.

${ }^{17}$ Tamże, s. 77.
} 
dla szczegółowych doświadczeń, pozwalając podjąć je w sposób wolny jako miejsce komunii z Bogiem. Tylko w Nim stają się dostępne wszelkie wartości, jak życie, zdrowie, obfitość dóbr, honor, pokój, dobra sława ${ }^{18}$. W tej perspektywie ostatecznego spełnienia także wszystkie rzeczy ofiarowane kiedyś człowiekowi zostaną mu powtórnie poddane: „Wszystkie na koniec rzeczy poddane nam będą, jako się oddamy Temu, który nam wszytko rzucił pod nogi"19.

Posłuszeństwo prowadzi do restauracji harmonii świata. Myśl ta sięga realiów ogrodu Eden, gdzie Adam jest panem ziemskich stworzeń (por. Rdz 1, 28), którym nadaje imiona (por. Rdz 2, 19-20). Ostatecznie świat poważnie naruszony przez grzech będzie odnowiony poprzez uległość. W tym wielkim procesie wolna decyzja człowieka odgrywa rolę przełomową, ponieważ pociąga za sobą możliwość uporządkowania wszystkiego. Zgodnie z Bożym planem akt wolnej woli sytuuje się pomiędzy przeszłością, gdy wszystko zostało złożone pod stopy człowieka, a przyszłością, kiedy wszystko będzie mu znowu poddane. W cytowanym fragmencie porządek ten wyrażają poszczególne zdania: pierwsze odnosi się do przyszłości, ostatnie do przeszłości, natomiast środkowe dotyczy najbliższej przyszłości, a właściwie teraźniejszości, w której ma być podjęta kluczowa decyzja otwierająca ustanowienie odnowionego ładu ${ }^{20}$.

W dalszym ciągu obraz ten łączy się ze wspomnianą wizją chrystocentrycznej odnowy:

Cum autem subiecta fuerint illi [Christo] omnia, tunc et ipse filius subiectus erit ei, qui subiecit sibi omnia, ut sit Deus omnia in omnibus $(1 \text { Kor } 15,28)^{21}$.

Staje się jasne, iż autorski wykład na temat roli człowieka został zbudowany na zasadzie paraleli do Pawłowego proroctwa, które zawiera następującą sekwencję: poddanie wszystkiego Chrystusowi, a następnie poddanie Chrystusa Ojcu. Człowiek poprzez akt posłuszeństwa odzyskuje pozycję pana stworzeń i ta „mała harmonia” w ostatecznej wizji jest częścią, „wielkiej harmonii” z Chrystusem - Panem i Pośrednikiem. Poddanie stworzeń człowiekowi uwarunkowane oddaniem się człowieka Bogu mieści się zatem w obrębie wyznaczonym przez zdanie: „Cum autem subiecta fuerint illi omnia"22. W akt wieńczący historię wpisuje się panowanie człowieka nad bytami ziemskimi, gdyż właśnie tak uporządkowany świat poprzez Chrystusa, jedynego Pośrednika, zostaje oddany Ojcu.

${ }^{18}$ Por. tamże, s. 74.

${ }^{19}$ Tamże, s. 77.

${ }^{20}$ Por. M. Zawada, Pokora - podstawy duchowej architektury, Warszawa 2004, s. 16-21.

${ }^{21}$ F. Birkowski, Kazania..., s. 76.

${ }^{22} \mathrm{~W}$,małej harmonii” akcentowana jest wolna decyzja człowieka, gdyż wyraz ,jako” można rozumieć przyczynowo na wzór fragmentu Modlitwy Pańskiej: „Odpuść nam nasze winy, jako i my odpuszczamy naszym winowajcom”. Oczywiście te dwa teksty nie zawierają tezy, że brak posłuszeństwa człowieka uniemożliwia poddanie bytów Jezusowi, ale właśnie bardzo mocno podkreślają miejsce przeznaczone dla ludzkiej osoby. 
Posłuszeństwo wiąże się ściśle z poznaniem prawdy, gdyż dzięki niemu osoba odczytuje, czym rzeczywistość jest i chroni się przez fałszywą wizją siebie i swego miejsca w świecie. Następuje oczyszczenie i uporządkowanie nazywane w obecnej terminologii porzuceniem fałszywego ,ja” na rzecz tego, które jest prawdziwe, czyli w pełni otwarte na zaspokojenie ze strony samego Boga ${ }^{23}$. Prezentowana tutaj postawa pozwala człowiekowi uczestniczyć w Bożym planie, co przynosi w efekcie wewnętrzną i zewnętrzną harmonię życia. Porzucenie własnych idei otwiera drzwi do poznania i doświadczenia Bożej mocy, której człowiek staje się współpracownikiem.

\section{Posłuszeństwo Chrystusa wzorem dla człowieka}

Birkowski przedstawia postać Chrystusa jako przykład posłuszeństwa do naśladowania przez człowieka. Tematy znalezienia i życia ukrytego w Nazarecie pozwalają na ukazanie głębi Jego poddania się Ojcu. Uległość łączy się z postawą służby, gdyż być posłusznym oznacza służyć, dlatego na podstawie Biblii Jezus nosi nazwę ,sługi”.

Autor gromadzi zbiór miejsc biblijnych odnoszących pośrednio lub bezpośrednio miano sługi do Chrystusa. Kolekcja tekstów: „Ecce servus meus” (Iz 42, 1); „Humiliavit semetipsum formam servi accipiens” (Flp 2, 7-8); „Ego sevus tuus” (Ps 116, 16), „servum meum David” (Ez 34, 23) $)^{24}$ stanowi argument indukcyjny i łączy się z pytaniem, jak wiele Pismo mówi o Jego posłuszeństwie. Z jednej strony pobyt w Nazarecie jest czasem milczenia. Polski autor zauważa potrzebę poznania, czym było wypełnione życie Zbawiciela przez tych osiemnaście lat, to jest między 12 a 30 rokiem życia. Podkreślając znamienny brak informacji, wydobywa jednak frazę: „Erat subditus illis” (Łk 2, 51), którą traktuje jako wystarczającą wiadomość o tym, czym zajmował się Jezus: otóż był posłuszny tak w trzynastym, jak w dwudziestym czy dwudziestym piątym roku życia ${ }^{25}$. Z drugiej strony całe Pismo Święte zawiera wypowiedzi o kimś, kto ma wypełnić wolę Boga (por. Ps 40, 8-9), które dotyczą Pana Jezusa: „co karta w Bibliej, to posłuszeństwo Chrystusowo bardzo znaczne”26. Wspomniany fragment psalmu przedstawia się następująco: „In capite libri scriptum est de me, ut facerem voluntatem tuam”27, a w polskiej wersji: „W głowie księgi napisano jest o mnie, abym czynił wolą twoję [Boże]"28.

\footnotetext{
${ }^{23}$ Por. M. Zawada, Pokora..., s. 28-30.

${ }^{24}$ F. Birkowski, Kazania..., s. 75.

${ }^{25}$ Por. tamże, s. 74.

${ }^{26}$ Tamże, s. 77. Por. M. Zawada, Pokora..., s. 6-10.

${ }^{27}$ F. Birkowski, Kazania ..., s. 77.

${ }^{28}$ Tamże, s. 84.
} 
„In capite libri” („w głowie księgi”) odnosi się do początku używanego przez Żydów zwoju, w którym jest on przytwierdzony do wałka ${ }^{29}$. W stosunku do Chrystusa słowa te, łącząc się z podobną deklaracją z Nazaretu (por. Iz 61, 1-2; Łk 4, 18-19), oznaczają, że temat wypełnienia woli Ojca przez Syna obejmuje całą Biblię ${ }^{30}$.

Posłuszeństwo dotyczy ludzkiej natury Chrystusa. Jest On nazwany sługą pod względem swego człowieczeństwa ${ }^{31}$, jednak na mocy zjednoczenia hipostatycznego oraz wymiany orzekań (communicatio idiomatum) cechy sługi zostają przypisane Bogu:

On, który wedle natury Boskiej Bogu Ojcu jest równy, wedle człowieczeństwa sługą się zowie, nie dla czego inszego jedno iż dostatecznie oddanym jest Ojcu, wolej jego posłuszny, [...] niczego nie pragnął, jedno wolą Ojcowską wypełniaćc ${ }^{32}$.

Konsekwencją Jezusowej tożsamości jest paradoksalne stwierdzenie: „Bóg sam w naturze ludzkiej sam sobie był poddany"33. Staje się to możliwe dzięki Wcieleniu, w którym Syn przyjmuje ludzką naturę, by cierpieć za grzeszników. Służba - wyraz posłuszeństwa, staje się wymiarem tego posłannictwa.

Postawa Zbawiciela powinna być rozpatrzona najpierw w odniesieniu do Jego Ojca. Wypełnienie woli Ojca jest jedynym pragnieniem Jezusa, o czym świadczą słowa: „[...] nie wiedzieliście tego, iż ja muszę być na robocie Ojca mego?” (Łk 2, 49) 34 . Świątynia staje się tu metonimią woli Ojca, pracy dla Niego. Jako człowiek Jezus daje przykład posłuszeństwa, pokory i służby, co oznacza, że osiągnięcie ostatecznych dóbr przez człowieka może się dokonać poprzez naśladowanie Chrystusa. Ta zależność wynika z trynitarnego planu, zgodnie z którym wcielone Słowo stało się sługą, aby człowiek nie chronił się przed służbą Bogu ${ }^{35}$. Dlatego autor zanosi do Boga prośbę o prawdziwe posłuszeństwo przez Jego posłusznego Syna ${ }^{36}$.

Będąc poddanym Ojcu, Syn Boży jest równocześnie sługą ludzi, szczególnie swej Matki i Opiekuna, św. Józefa. Birkowski przypisuje Jezusowi niby zmianę stanowiska, gdy w Świątyni, zadeklarowawszy wolę służenia Ojcu, odkłada tę pracę do wieku trzydziestu lat, czyli rozpoczęcia publicznej działalności ${ }^{37}$. Jednak poprzez retoryczne correctio polski autor utrzymuje, iż posłuszeństwo (i służba) względem

${ }^{29}$ Por. tamże.

${ }^{30}$ Do tego szerokiego ujęcia można jeszcze dołączyć tezę F. Varillona, wedle której pokora jest sposobem bycia Boga. Por. F. Varillon, Pokora Boga, thum. W. Sukiennicka, Warszawa 1977, s. 149, cyt. za: W. Zatorski, Pokora, Kraków 2008, s. 48.

${ }^{31}$ Por. tamże, s. 74.

${ }^{32}$ Tamże, s. 75.

${ }^{33}$ Tamże.

${ }^{34}$ Tamże, s. 82-83.

${ }^{35}$ Por. F. Birkowski, Kazania..., s. 75.

${ }^{36}$ Por. tamże, s. 81.

${ }^{37}$ Por. tamże, s. 84. 
Matki było w istocie formą wypełnienia obowiązku względem Ojca ${ }^{38}$. Postawa Zbawiciela analizowana jest w oparciu o werset: „Erat subditus illis” (Łk 2, 51) z pomocą alegorii starotestamentalnej sceny zatrzymania się Słońca i Księżyca na głos Jozuego (por. Joz 10, 12-14). Ów wyjątkowy cud przewyższają jednak realia życia Jezusowego. Relację tę ujmuje seria paralelnych zestawień. Pierwsze dotyczy mocy głosu ludzkiego, jeśli bowiem głos Jozuego rozkazuje ciałom niebieskim, to głos Maryi kieruje postępowaniem samego Boga. Nie tylko Słońce i Księżyc stały się posłuszne człowiekowi, ale sam Bóg w swej ludzkiej naturze. Podobnie z motywem zatrzymania: o ile przedtem zatrzymało się ciało niebieskie, o tyle teraz sama Mądrość Boża zatrzymała się w domku nazaretańskim. Alegoreza przybiera jeszcze bardziej skomplikowany kształt, gdy pojawia się twierdzenie, iż w Starym Przymierzu Słońce i Księżyc były poddane człowiekowi noszącemu imię Jezus („Jozue” odpowiada imieniu „Jezus”), a w Nowym Jezus jest posłuszny Słońcu, czyli Maryi, i Księżycowi, czyli Józefowi. Jeszcze jedna różnica kryje się w ilości: pierwszy cud wydarzył się tylko raz, a drugi tysiąc razy dziennie ${ }^{39}$. Ilość takich analogii opartych na kontrastach objawia głębię Jezusowej pokory, w której realizuje się Boży plan.

Obok rodziców Chrystus jest poddany także innym ludziom, co deklaruje w słowach: „Ego autem in medio vestrum, sicut qui ministrat” (Łk 22, 27). Ten aspekt służby przewija się przez całe Jego życie:

Król on wielki, on Biskup nawyższy, prawdziwy Syn Boży uczniom swym prostaczkom służył: służył do stołu, wielki małym usługował. Podobno nie tylo przy ostatecznej wieczerzy, ale często on to czynił, służył jako sługa nie tylo uczniom, ale i drugim dobrym i złym był posłuszny ${ }^{40}$.

Posłuszeństwo nieskończonego Boga nosi na sobie cechę uniwersalizmu i obejmuje służbę uczniom, ujętą w ramy kryterium ilościowego, ale także poddanie względem ludzi złych, zwłaszcza w czasie Męki, a nawet wobec złego ducha, gdy Jezus pozwala się postawić na narożniku Świątyni (por. Łk 4, 9). Granicą uległości jest jednak Boży zamiar, który dopuszcza spotkanie ze złem dla objawienia wyższego dobra. Kuszenie kończy się przywołaniem słów Pisma, a wydarzenia pasyjne odsłaniają ostatecznie wielki akt posłuszeństwa Syna wobec Ojca.

Postać Chrystusa stanowi przykład dla duchowego życia. Jego oddanie tworzy pierwszą część argumentu (a fortiori) wyznaczającego przestrzeń ludzkiego działania. Przedstawia się on następująco: skoro Pan służył mniejszym od siebie, to i chrześcijanin, dla Jego miłości, ma służyć mniejszym niż on $\mathrm{sam}^{41}$. Podobną

${ }^{38}$ Por. tamże. Zależność tę ilustruje przykład koła, w którym obwód osiąga cel w swym punkcie wyjścia. Podobnie Jezusowe posłuszeństwo zaczyna się od Ojca i powraca do Niego poprzez posłuszeństwo względem Matki.

${ }^{39}$ Por. tamże. Można tu dostrzec jeszcze tę różnicę, że zatrzymanie ciał niebieskich było znakiem widzialnym, a Boska tożsamość Jezusa pozostawała ukryta.

${ }^{40}$ F. Birkowski, Kazania..., s. 77.

${ }^{41}$ Por. tamże, s. 78. 
formą jest pytanie: „Poddany był Chrystus Jezus poddanym swoim, a my czemu Bogu nie oddajemy poddaństwa?"42.

Pełna perswazja wygląda tak: jeśli Jezus (wielki) był poddany ludziom (małym), to tym bardziej ludzie (mali) powinni być poddani Bogu (wielkiemu). Odmienność stanu rzeczy sugeruje pytanie retoryczne. Ten apel przez strukturę chiazmu odwołuje się do zasad sprawiedliwości oraz uczucia wstydu z powodu ich niezachowania. Podobnie zresztą jest uzasadniana konieczność oddania ciała w akcie posłuszeństwa. Jeśli bowiem Jezus tak czynił, to tym bardziej powinni tak czynić Jego uczniowie ${ }^{43}$. Podstawę dla tego typu argumentów można dostrzec w słowach Zbawiciela, który twierdził, że uczeń nie przewyższa nauczyciela i że powinien go naśladować (por. Mt 10, 24-25).

Posłuszeństwo Jezusa posiada wartość totalną nie tylko w swym zakresie obejmującym wolę Ojca wraz z poddaniem względem ludzi, ale także w całościowym zaangażowaniu Jego ludzkiego życia poprzez ofiarę ciała, rozumu i woli. Również to osobiste oddanie stanowi wzór do naśladowania przez człowieka.

\section{Osobiste zaangażowanie w posłuszeństwo wobec Boga}

Posłuszeństwo tworzy program obejmujący całe ludzkie życie, także w jego strukturze wewnętrznej. Przyjęcie Bożej woli i naśladowanie Chrystusa w Jego całkowitym oddaniu się Ojcu oznacza pełne zaangażowanie osobistego życia aż po jego przemianę. Wyraża się ono w poświęceniu ciała i duszy z jej władzami - rozumem i wolą.

Działanie sługi ilustruje przykład króla Dawida w przypisanej mu mowie (sermocinatio):

obróciłem nogi moje na świadectwa twoje. Affekty moje obróciłem do woli twojej i postanowiłem to u siebie zawsze cię słuchać (por. Ps 119). Dostateczne poddaństwo ze mnie oddajęć, Boże mój, nie szukam woli mojej, wolą twoją czynić obiecuję, nie odwiodą mię od niej udręczenia, obmowiska, strachy, nie odejdę od doskonałości $[\ldots]^{44}$.

Zasadnicze znaczenie posiada akt wolnej woli, którego skutkiem jest zwrócenie całego życia wewnętrznego (afekty, wola) i zewnętrznego („nogi”) do Bożych przykazań. Akt ten obejmuje wybór Boga, odrzucenie własnej woli jako reguły życia oraz pokonywanie przeszkód. Rezultatem jest trwale ukształtowane złączenie z Bogiem związane też z niebieską nagrodą ${ }^{45}$.

Człowiek powinien oddać Bogu w akcie posłuszeństwa swoje ciało na wzór ofiary Chrystusa. Większą uwagę autor przywiązuje jednak do kwestii ofiarowania woli i wyraża ten postulat w alegorycznym wykładzie wersetu: „Pectusculum erit

\footnotetext{
${ }^{42}$ Tamże, s. 79.

${ }^{43}$ Por. tamże, s. 80.

${ }^{44}$ Tamże, s. 77.

${ }^{45}$ Por. F. Birkowski, Kazania..., s. 80.
} 
Aaron et filiorum eius, armus quoque dexter de pacificorum hostiis cedet in primitias Sacerdotis" $\left(\operatorname{Kpł~7,~3-32)~}{ }^{46}\right.$.

Zarówno pierś (,pectusculum”) jak i prawa łopatka (,armus”) mają tu być ofiarowane ,starszym”. Dwa elementy zwierzęcia ofiarnego oznaczają dwa obszary ludzkiego życia, odpowiednio wolę i pracę, ponieważ pierś łączy się znaczeniowo $\mathrm{z}$ życiem wewnętrznym, a kończyna $\mathrm{z}$ aktywnością zewnętrzną. Birkowski podkreśla w ten sposób konieczność integralnego podporządkowania człowieka Bogu reprezentowanemu przez ludzi:

piersi trzeba oddać posłuszeństwu i owszem pokorne piersiczki, to jest wolą pełną pokory, łopatkę też oddajmy albo ramię, któreby było gotowe na zniesienie ciężarów nałożonych. Nie dosyć na tym roboty czynić, a wolej nie przyłożyć, nie dosyć wolą oddać, a pracej się chronić, trzeba obojga: wola z uczynkami gotowa, wolej starszego oddana, ma być ofiarowana ${ }^{47}$.

Zaangażowanie człowieka musi być zatem integralne, gdyż tylko taka postawa pozwala trwać w prawdzie o sobie i nie ulegać iluzji łatwiejszego sposobu życia. Każde naruszenie związku tego, co wewnętrzne, z tym, co zewnętrzne, wytwarza taką fałszywą wizję. $Z$ drugiej strony daleko idące wymagania sformułowane na tle filozofii realistycznej i teologii nowożytnej stoją na straży dobra człowieka, które posiada charakter obiektywny ${ }^{48}$.

Istotę zaangażowania w posłuszeństwo przybliża także motyw ucha przebitego na znak dobrowolnej decyzji niewolnika, aby pozostać do końca życia w domu swego pana jako jego sługa (por. Wj 21, 6). Przekłute ucho łączy się tu poprzez cechę otwarcia z uchem ,dziurawym”, czyli takim, które pozwala na przepływ głosu. Autor tak objaśnia tę zależność:

Chrześcijanin, który woli być u Pana Boga sługą niż na świecie wolnym abo swowolnym niechaj ma ucho dziurawe, którego się prędko ująć może starszego roskazanie, niechaj go nie zatyka hardość ani miłość własna, niechaj go pokora otwiera i wola skłonna na posłuszeństwo. Takie miał uszy Chrystus Jezus, bo tak w osobie jego mówi Psalmista: „Sacrificium et oblationem noluisti, aures autem perfecisti mihi” [...] (Ps 40,7). Dziurawe uszy, uszy są doskonałe i otworzone, nie zatkane złemi humorami ${ }^{49}$.

„Dziurawe” ucho funkcjonuje jako znak głębokiego zaangażowania w dzieło posłuszeństwa. Początek, niby przebicie, stanowi tu akt ofiarowania siebie Bogu poprzez odwrócenie się od wartości ,światowych” i własnych idei. W dalszym ciągu pojawia się natomiast konieczność pielęgnowania życia duchowego. Utrzymanie

${ }^{46}$ Tamże.

${ }^{47}$ Tamże.

${ }^{48}$ Rozważania Birkowskiego zostały opublikowane w czasie, w którym dojrzewała myśl Kartezjusza głosząca odwrót od filozofii bytu i zwrot ku filozofii świadomości. Odrzucenie tego paradygmatu oderwało człowieka od poszukiwania szczęścia poprzez podporządkowanie obiektywnemu prawu Bożemu. Por. Jan Paweł II, Pamięć i tożsamość. Rozmowy na przełomie tysiącleci, Kraków 2005, s. 15-19. W tym sensie kartezjanizm stanowi wielkie wyzwanie dla nauki Kościoła głoszonej przez Birkowskiego.

${ }^{49}$ F. Birkowski, Kazania..., s. 81. 
„dziurawego" ucha oznacza stałą troskę o trwanie w posłuszeństwie poprzez przyjmowanie głosu zewnętrznego autorytetu, w czym przeszkodą jest miłość własna czy negatywne afekty, zaś pomocą służy dobrowolna pokora. Także tutaj postawa Chrystusa stanowi wzór współpracy człowieka z Bogiem, bo i ucho Zbawiciela zostało otworzone dla pełnienia woli Ojca ${ }^{50}$. Przebicie ucha jest dziełem Boga, natomiast podjęcie konsekwencji tego aktu należy już do człowieka.

Mówiąc o zaangażowaniu, Birkowski porusza też kwestię posłuszeństwa rozumu, gdyż otwarte ucho oznacza postawę słuchania Bożego głosu, a zatem akt poznania. Zarówno poddanie woli, jak i rozumu są ściśle ze sobą połączone, ponieważ służba Bogu zakłada uprzednie zrozumienie Jego woli. Prawdziwie posłuszny człowiek podporząadkowuje swój rozum Bogu: ,[...] pogrzebł wszytkie swoje diskursy w grobie; już pomarły, sam tylo diskurs starszego żyje" ${ }^{51}$.

Metafory pogrzebu i grobu sugerują ostateczny i nieodwracalny stopień przekształcenia życia, podobny do tego ukazanego przez św. Pawła w nauczaniu o śmierci chrześcijanina dla grzechu i życiu dla Boga (por. Rz 6, 1-14). Pogrzeb oznacza wyrzeczenie się własnego sądu (,diskursu”) dla jego negatywnych skutków $^{52}$. Podobnie alegoria grobu przygotowanego przez Abrahama dla siebie i swej żony (por. Rdz 23, 17-20; 24, 7-10) zwraca uwagę na konieczność „pogrzebania” obydwu wyższych władz duszy, czyli rozumu i woli ${ }^{53}$ i podobnie jak w wypadku alegorii o ofiarowaniu piersi i łopatki podkreśla konieczność integralnej ofiary.

W strukturze posłuszeństwa pomiędzy człowiekiem a Bogiem pojawia się postać pośrednika określonego słowem „starszy”. Jest to ktoś reprezentujący Boga, tożsamy z przełożonym. Jego autorytet posiada nadprzyrodzoną genezę. Birkowski twierdzi jasno: „Boga słucham, gdy człowieka słucham” i ,głos starszego, głos jest Boży”54, co koresponduje z Jezusową zasadą: „Qui vos audit, me audit, qui vos spernit, me spernit” (por. Łk 10, 16). Starszy obrany zgodnie z prawem „Bogiem jest" 55 . Poza wzywaniem do grzechu głos przełożonego ma być przyjmowany natychmiast i bezwarunkowo. Wzorem jest tu także św. Piotr, który na głos Jana obwieszczającego tożsamość postaci na brzegu niezwłocznie rzucił się w morze (por. J 21, 7-8). Podobnie:

posłuszny człowiek, skoro usłyszy: „na miejscu Bożym ten jest mój starszy”, zaraz bieży, a czyni roskazanie jego, by było nie wiem jako nie w smak, słone jako morze, gorzkie jako żółćc5.

\footnotetext{
${ }^{50}$ Przyjmując lekcję Hieronima, Birkowski czyta „perfecisti” jako „fodisti”, a czasownik „fodio, fodere” oznacza „przebijać, przekłuwać” i jest bliski znaczeniu „otworzyć”.

${ }^{51}$ F. Birkowski, Kazania ..., s. 81.

${ }^{52} \mathrm{~W}$ tak pozytywnym nauczaniu Filotei o ludzkim wyborze powiedziano, że prawie zawsze sprawia pomniejszenie cnoty. Por. F. Salezy, Filotea..., s. 143.

${ }^{53}$ Por. F. Birkowski, Kazania..., s. 81.

${ }^{54}$ Tamże, s. 79.

${ }^{55}$ Tamże.

${ }^{56}$ Tamże.
} 
Kluczowym momentem alegorii jest ten, w którym Piotr uwierzył w prawdziwość słów Jana i potwierdził tę wiarę przez działanie. Słowo człowieka, Jana, występującego w roli autorytetu, przyjęte z wiarą umożliwiło spotkanie z Chrystusem. Zdecydowana reakcja Piotra oznacza, że chrześcijanin powinien z podobną energią podjąć polecenia przełożonego, nie pozwalając, aby przeszkodziły temu żadne trudności, oznaczane przez smak gorzki lub słony. Jako reprezentant Boga „starszy” jest pasterzem troszczącym się o bezpieczeństwo i potrzeby poddanych, a jego „rózga”, znak autorytetu i władzy, oznacza także opiekę (por. Ps 23, 4) ${ }^{57}$. W miejscu starszych pojawiają się także najmniejsi członkowie Kościoła, gdyż stanowią oni jakby stopy samego Chrystusa, tak że uczczenie ich ${ }^{58}$ jest aktem skierowanym ku Zbawicielowi wynagradzającemu człowieka szczególnym objawieniem swej miłości. Dobrowolne uniżenie staje się koniecznym warunkiem wywyższenia dokonanego przez Boga, które pełniej ujawnia pozytywny sens całego procesu ${ }^{59}$.

\section{Mistyczny wymiar posłuszeństwa}

Na drodze chrześcijańskiego posłuszeństwa może wystąpić także specyficzne doświadczenie, gdy człowiek przeżywa w swej świadomości nieobecność Chrystusa i jest to dla niego tak trudne, jak dla Maryi trzydniowe poszukiwanie Syna. Doświadczenie to staje się udziałem ludzi utwierdzonych w sprawiedliwości, bo w ten sposób Bóg przygotowuje ich do ściślejszego zjednoczenia ze sobą. Przyjmując te trudności, człowiek aktualizuje swą pokorę i wysoki stopień posłuszeństwa, ponieważ ich wartość objawia się i wzrasta szczególnie w rzeczach trudnych do akceptacji, jak w życiu samego Zbawiciela (por. Hbr 5, 8).

Podczas modlitwy Bóg „opuszcza sprawiedliwych” poprzez odebranie im duchowego zadowolenia określanego jako: „wdzięczny wietrzyk nabożeństwa”, ,słodka rosa smaków duchownych". Dla oddania tego stanu Birkowski stosuje werset psalmu: „In die tribulationis meae Deum exquisivi, manibus meis nocte contra eum et non sum deceptus" (por. Ps 77, 3), odnosząc słowa ,in die tribulationis” oraz „nocte” do tego stanu opuszczenia, w którym sprawiedliwy intensywnie poszukuje obecności Zbawiciela. I chociaż w rzeczywistości Bóg pozostaje wciąż blisko niego, to człowiek o tym nie wie. Autor zamieszcza opis tego stanu:

Bywa i to, iż Bóg światłość onę w rękach swych zamknie, niedaleko będzie sprawiedliwej dusze, a ona rozumie, iż daleko kędyś jest i rozumie, iż zginął i gorzko płacze. Tej suchości duchownej dał imię Dawid święty nocy i dnia. Dzień jest, abowiem Boga ma obecnego z łaską swoją, noc jest, abowiem się nie pokazuje, na oczy nasze nie idzie, tylo na górnej części dusze naszej jest i przy rozumie tylo, zmysły o tym nie wiedzą ${ }^{60}$.

${ }^{57}$ Por. tamże, s. 79.

${ }^{58}$ Por. tamże, s. 78.

${ }^{59}$ Schemat wstępowania i zstępowania stanowi klasyczny sposób rozważania o dynamice pokory i związanych z nią owocach. Por. W. Zatorski, Pokora, s. 68-75.

${ }^{60}$ Tamże, s. 85. 
Dwie pory odsłaniają dwa wymiary doświadczenia. „Dzień” oznacza obiektywny porządek, w którym dusza pozostaje obiektem działania przebywającego w niej Boga, podczas gdy „noc” odnosi się do jej subiektywnego przekonania o braku Bożej obecności i do niewiedzy o istocie całego przeżycia.

Wypowiedź autora przywołuje teologiczne zasady życia mistycznego ${ }^{61}$. Z jednej strony Bóg jest blisko umysłu, w którym koncentruje się życie człowieka, a więc przebywa $\mathrm{w}$ centrum jego duszy. $\mathrm{Z}$ drugiej strony intelekt potrzebuje do poznania zmysłów, bo one dostarczają danych przekształcanych następnie w pojęcia i sądy. Zwyczajny sposób poznawania polega na rozumieniu w oparciu o zmysły połączone z wyobraźnią. Tymczasem w opisywanym stanie człowiek zostaje wezwany do przebywania z Bogiem bez żadnej pomocy ze strony życia zmysłowego. Wszystko to przywołuje zarówno klasyczne nauczanie św. Tomasza z Akwinu ${ }^{62}$ na temat poznania, jak i naukę o początkach kontemplacji wlanej. Z tej racji, że istotą kontemplacji ze strony człowieka jest akt intelektu ${ }^{63}$, można przyjąć, że Bóg przebywając „przy rozumie tylo”, przygotowuje duszę do kontemplacji wlanej, określanej jako: „proste i serdeczne poznanie Boga i Jego dzieł, będące owocem nie działania ludzkiego wspomaganego łaską, lecz szczególnego natchnienia Ducha Świętego"64. Opis Birkowskiego koresponduje z opisem nocy ciemnej zmysłów pozostawionym przez św. Jana od Krzyża. Wchodząc na drogę mistycznych przeżyć, człowiek nie znajduje pociechy ani w rzeczach Bożych, ani w stworzeniach i przeżywa niemożność rozmyślania o Bogu, chociaż szuka Go w pamięci i poprzez bolesny niepokój ${ }^{65}$. W rzeczywistości Bóg w ten sposób wpływa na wyższe władze duszy, zwłaszcza na intelekt jako organ kontemplacji. Trudność doświadczenia leży w tym właśnie, że obiektem Bożego działania staje się sam umysł, poza dotychczas ukształtowaną relacją do zmysłów ${ }^{66}$ :

Przyczyną oschłości w ciemnej nocy jest to, że Bóg zamienia pociechy i siły zmysłowe na duchowe. Ponieważ zaś zmysły i ich działanie naturalne nie są zdolne pojąć tych rzeczy duchowych, pozostają głodne, oschłe i puste. Zmysłowa część człowieka nie może objąć tego, co jest czystym duchem [...]. Duch zaś umocniony takim pokarmem nabiera sił i większej energii, by jak najlepiej służyć Bogu. To zaś, że w początkach nie odczuwa słodyczy i przyjemności duchowej, tylko oschłość i niesmak, jest na skutek nowości tej zmiany ${ }^{67}$.

${ }^{61} \mathrm{~W}$ tym miejscu myśl autora zostaje ukazana w świetle teologii duchowości, aby podkreślić, jak interesująco i rzetelnie Birkowski pisze o mistyce. Systematyczny wykład nauczania zawiera klasyczne dzieło: R. Garrigou-Lagrange, Trzy okresy zycia wewnętrznego wstepem do życia w niebie, tłum. T. Landy, Niepokalanów 2001.

${ }^{62}$ Por. E. Gilson, Tomizm. Wprowadzenie do filozofii św. Tomasza z Akwinu, Warszawa 1960, s. 282-332.

${ }^{63}$ Zob. św. Tomasz z Akwinu, Suma teologiczna, I-II, q. 45, a. 2-6.

${ }^{64} \mathrm{R}$. Garrigou-Lagrange, Trzy okresy..., III 31.

${ }^{65}$ Por. tamże, III 4.

${ }^{66}$ Pozostaje ona w każdym razie nieaktywowana.

${ }^{67}$ R. Garrigou-Lagrange, Trzy okresy..., III 4. 
Należy tu dołączyć fragment opuszczony w polskim tłumaczeniu dzieła, który podkreśla moment przezwyciężenia tego swoistego kryzysu:

duch, chociaż początkowo bez żadnej słodyczy [...] staje się świadomy mocy i energii do działania na mocy substancjalnej natury swego wewnętrznego pokarmu, który jest początkiem kontemplacji, ciemnej i oschłej dla zmysłów ${ }^{68}$.

Garrigou-Lagrange wyjaśnia, że źródłem trudności jest nowy sposób Bożego działania, który dotyka bezpośrednio ludzkiego intelektu, pomijając zmysły. Pomimo uczucia pustki duch jest karmiony przez Boga nowym, czysto wewnętrznym pokarmem kontemplacji wlanej, który jako pochodzący od Boga dostarcza nowych sił. Ludzka ciągła troska o mistyczną relację z Bogiem polegać będzie na unikaniu zaniedbań i przyjmowaniu nowego pokarmu w nowy sposób.

Chociaż w mistyce dominantą jest działanie Ducha Świętego, to jednak człowiek powinien współpracować z łaską przez ciągłe poszukiwanie Boga. Ów drugi ze znaków początków kontemplacji można odnieść do opisu Birkowskiego. Polski kaznodzieja używa motywu ręki poszukującej Boga jak również obrazu ćwiczenia duchowego traktowanego jako ciężka praca z takimi elementami, jak padanie na kolana, składanie rąk, łzy, gorące westchnienia, ogniste słowa ${ }^{69}$. Początki życia mistycznego wymagają pełnego zaangażowania osoby, by móc zyskać bardziej wzniosłe dary.

Kontemplacja bywa przyswajana we właściwy sobie sposób: jest „rozumiana” „duchem, a nie zmysłami” i przyjmowana w „szkole miłości” „sercem, a nie oczyma”. Te wyrażenia podkreślają, że stanowi wiedzę wewnętrzną, uniezależnioną od zmysłów i w dużym stopniu afektywną ${ }^{70}$. Precyzując, autor stwierdza:

Smakuje to rada wola sama, do której są one słowa: „Skosztujcie, a obaczcie, jako wdzięczny jest Pan" (por. Ps 34, 9). Im więcej smaku tego w delicjach Boskich przybiera dusza, tym barziej poznawa, iż łakomiej miłuje ${ }^{71}$.

„Kosztowanie” Boga staje się tutaj kluczowym słowem określającym doświadczenie kontemplacji ${ }^{72}$. Sekwencja słów: „Skosztujcie, a obaczcie” oznacza, że doświadczenie Boga poprzedza wiedzę o Nim, co stoi w opozycji do zwykłego

${ }^{68}$ R. Garrigou-Lagrange, The Three Ages of the Interior Life, III 4, www.christianperfection.info/ tta80.php\#bk2 (02.06.2012), fragment thum. M. Godawa.

${ }^{69}$ Por. F. Birkowski, Kazania..., s. 87; Ps 126, 5-6.

${ }^{70}$ Por. F. Birkowski, Kazania..., s. 86. Słowa „nie od rozumu, ale od afektu” nie oznaczają wyłączenia rozumu jako takiego, skoro wcześniej mowa o „rozumieniu”, ale wzniesienie się ponad jego spekulatywną działalność, by przyjąć światło kontemplacji. T. Merton pisze: „Mistyczne poznanie Boga jest sądem, lecz sądem ponad pojęciami. Jest to poznanie zapisujące się w duszy biernie, bez żadnego pojęcia” (T. Merton, Szukanie Boga, tłum. P. Parlej, Kraków 1983, s. 75). Dzisiaj występuje zresztą wyraźna tendencja do mówienia o mistyce w kategoriach raczej świadomości niż doświadczenia, a więc z podkreśleniem wątku poznania, które przekracza jednak zwyczajny porządek. Por. B. McGinn, Fundamenty mistyki (do V wieku), tłum. T. Dekert, Kraków 2009, s. XVIII-XXII.

${ }^{71}$ F. Birkowski, Kazania..., s. 86.

${ }^{72}$ Por. A. Słomkowski, Teologia życia duchowego, Ząbki 2000, s. 279. 
sposobu odżywiania, w którym najpierw trzeba poznać pokarm. Pierwszeństwo doświadczenia oddaje dobrze charakter Bożego działania w kontemplacji wlanej.

Zostaje tu także sformułowane ważne prawo osiągania duchowej obfitości, zgodnie z którym nasycenie pociąga za sobą większe łaknienie, które z kolei ma zostać zaspokojone. Widać tu wzajemną relację pomiędzy wypełnieniem a niewypełnieniem czy aktem a potencją. Aktualizacja powiększa zakres potencji, która domaga się tym samym wyższej jeszcze aktualizacji. Sposób przyswajania sobie pokarmu kontemplacji jest więc dynamiczny i rosnący ${ }^{73}$. Naprzemienność nasycenia i pragnienia pozwala duszy powiększać swą zdolność przyjmowania, a w ten sposób poprzez życie mistyczne prowadzi do życia wiecznego. Chociaż stan oschłości przypomina piekło ${ }^{74}$, to jednak droga duszy na nim się nie kończy. Człowiek posłuszny jest prowadzony do głębszego, mistycznego doświadczenia smaku rzeczy Bożych. Po koniecznym oczyszczeniu drogą oświecenia wstępuje on w przestrzeń zjednoczenia z Bogiem przedstawioną jako ziemia owocująca bez pracy ludzkich rąk. W ten sposób zostaje zobrazowana idea dominującego w mistyce działania Ducha Świętego. Pomiędzy takimi owocami, jak pobożne myśli i dzieła znajduje się także dar nadziei ${ }^{75}$, ponieważ obecny stan sytuuje się między czysto ziemskim a niebiańskim i pomimo tego, że mistyk jest zasadniczo wolny od przywiązania do grzechu, to jednak jego doświadczenie nie dorównuje jeszcze błogosławionemu szczęściu świętych.

Kazania Fabiana Birkowskiego (1566-1636) zawierają głęboką wizję posłuszeństwa, która tworzy program duchowego życia. Posłuszeństwo jest odpowiedzią osoby ludzkiej w jej egzystencjalnej kondycji na Boże zaproszenie oraz sposobem zyskania darów przygotowanych przez Boga. Podporządkowanie człowieka Stwórcy stanowi też przełomowy punkt restauracji harmonii uniwersum świata, by ostatecznie wszystko przez Chrystusa zostało oddane Bogu Ojcu, a Bóg był „wszystkim we wszystkich” jako ostateczne wypełnienie pragnień ludzkiego serca. Postawa Chrystusa, zwłaszcza w Jego życiu ukrytym, służy za wzór postępowania. Generalna zasada wypełnienia woli Ojca zawiera w sobie służbę rodzicom, innym ludziom, a nawet względną uległość wobec zła, by w ten sposób zrealizować plan zbawienia świata.

W obrębie tej perspektywy każdy naśladowca Chrystusa jest wezwany do pełnego osobistego zaangażowania, które obejmuje zarówno zewnętrzne działanie, jaki wewnętrzne akty rozumu i wolnej woli. Dzięki nim człowiek odwraca się od subiektywnego pojmowania szczęścia, by odnaleźć je w porządku obiektywnym, a poprzez posłuszeństwo

${ }^{73}$ Zasadę tę czerpie Birkowski od Grzegorza Wielkiego. Por. F. Birkowski, Kazania..., s. 86, ale ma ona genezę biblijną w Syr 24, 21 oraz w J 4, 13n.

${ }^{74}$ Por. F. Birkowski, Kazania..., s. 85-86.

${ }^{75}$ Por. tamże, s. 86. 
przełożonym i najmniejszym ludziom dostąpić wywyższenia i nagrody. Specyficznym wymiarem posłuszeństwa jest jeszcze życie mistyczne, w którym zwyczajny sposób współpracy z łaską zastąpiony zostaje biernym podporządkowaniem Bogu, aby ludzki duch mógł być karmiony nowym pokarmem kontemplacji. Doświadczeniem tym kieruje prawo duchowego nasycenia, zgodnie z którym osiągnięcie pewnych dóbr otwiera nowe możliwości przyjęcia darów jeszcze większych.

Nauczanie Birkowskiego odzwierciedla zalety wczesnonowożytnej teologii Kościoła katolickiego, zwłaszcza optymistyczną wizję człowieka, który poprzez współpracę z łaską odwraca się od dezintegracji grzechu ku Bożej woli wskazującej na prawdziwe, obiektywne szczęście. Nauczanie i życie Kościoła, określając reguły postępowania i łącząc człowieka ze źródłem nadprzyrodzonej mocy, umożliwiają kształtowanie ludzkiego doświadczenia pod względem wyboru celów, form i intensywności. Program posłuszeństwa sformułowany przez polskiego autora stanowi interesujące ujęcie na tle polskiej duchowości, która w latach dwudziestych XVII wieku znajdowała się już w fazie intensywnego rozwoju. Kazania te można czytać w kontekście publikacji Akademii pobożności (Kraków 1628) innego dominikanina, Mikołaja z Mościsk, która stanowi systematyczny wykład zagadnień życia moralnego i duchowego. Obydwaj autorzy wykazują znajomość zagadnień mistycznych w relacji do ożywienia tego rodzaju życia w Europie, czego śladem prowadzącym do Polski są choćby przekłady mistyków karmelitańskich dokonane przez Andrzeja Brzechffę w początkach stulecia, które okazało się tak ważnym okresem w polskiej duchowości.

\section{Summary}

\section{Dimensions of obedience in selected sermons by Fabian Birkowski OP (1566-1636)}

Birkowski's sermons show a deep vision of obedience which constitutes a program of spiritual life with its particular dimensions. Obedience as a man's response to God's plan is a way of getting all goods prepared by God and God alone, i.e. an ultimate accomplishment of a human heart. This posture means a crucial point of restoration of harmony of creatures made in relation to Jesus through Him the universe is subordinated to the Father. Christ's submission embraces fulfilment of the Father's will which expresses itself in service to people and in undergoing an evil in order to redeem the world. Inside this perspective every follower of Christ has to involve his whole spiritual life in obedience so that the corporal offering is supplemented by an act of free will and reason to turn from subjectivism towards real happiness. A very specific dimension of obedience concerns mystical life in which human ordinary way of cooperation with grace is to be replaced by mystical passivity. Thanks to it man is being nourished with new food of contemplation in a rhythm of progressive gratification.

The Birkowski's apprehension reflects good points of early modern Catholic theology that is an optimistic vision of man and his liaison with grace. This program enables him to shape his spiritual experience in every respect by supplying rules of life and divine power. The complete system formulated by Birkowski can be regarded as an outstanding achievement against the background of Polish early modern spirituality along with Akademia pobożności (Krakow 1628) by the other Dominican Mikołaj Mościcki. Their mystical threads are also an interesting issue at the beginning of the XVII c., which turned out a flourishing period called later A Golden Age of Polish Spirituality. 


\section{Keywords}

The elders, following Christ, God's will, harmony of the universe, humility, infused contemplation, involvement of will and reason in obedience, mystical purification, obedience, objective happiness, passivity, service 